\title{
Evaluation of the Cost of Production of Fish Clarias gariepinus Burchell, 1822 (Siluriformes, Clariidae) with Three Types of Food Based on Local Agricultural by-products in the Democratic Republic of Congo
}

\author{
Victor Pwema Kiamfü, ${ }^{1,2}$, Alex Mayoni Matondo², Santos Kavumbu Mutanda ${ }^{1,2}$, Clément Munganga Kilingwa ${ }^{1,2}$, \\ Nadine Bipendu Muamba ${ }^{3}$, Athanase Kusonika Ndamba ${ }^{4} \&$ Willy Lusasi Swana ${ }^{1,2}$ \\ ${ }^{1}$ Laboratory of Limnology, Hydrobiology and Aquaculture, Department of Biology, Faculty of Sciences, \\ University of Kinshasa (UNIKIN), Democratic Republic of Congo \\ ${ }^{2}$ Department of Biology, Faculty of Sciences, University of Kinshasa (UNIKIN), Democratic Republic of Congo \\ ${ }^{3}$ Laboratory of Inorganic Chemistry, Department of Chemistry, Faculty of Sciences, University of Kinshasa \\ (UNIKIN), Democratic Republic of Congo \\ ${ }^{4}$ Laboratory of Ecotoxicology and Ecosystem Health, Department of Environmental Sciences, Faculty of Sciences, \\ University of Kinshasa (UNIKIN), Democratic Republic of Congo \\ Correspondence: Willy Lusasi Swana, Laboratory of Limnology, Hydrobiology and Aquaculture, Department of \\ Biology, Faculty of Sciences, University of Kinshasa (UNIKIN), P.O Box 190 Kinshasa XI, Democratic Republic \\ of Congo. Tel: 243-813-662-026. E-mail: willy.lusasi@unikin.ac.cd
}

Received: April 4, 2020 Accepted: April 28, 2020 Online Published: May 19, 2020

\begin{abstract}
Clarias gariepinus Burchell, 1822 is a catfish with high commercial value in the Democratic Republic of Congo and in several African countries. The breeding of this species is controlled, but Congolese fish farmers are confronted with the problem of a lack of compound feed in the form of granules. The recovery of local agricultural waste would be essential to fill this gap. The objective of this study is to evaluate the effect of three types of food based on local agricultural by-products on the growth of $C$. gariepinus. The $25 \%, 41 \%$ and $51 \%$ crude protein feed formulas were tested in duplicate for 96 days. Fry averaging $2.20 \pm 0.43 \mathrm{~g}$ were distributed in 6 closed-loop plastic containers. The fish were fed twice a day by hand. Weighing and measuring took place every 14 days. The results obtained show that the highest final average weight $(\mathrm{g})$ and specific growth rate $(\% / \mathrm{d})(\mathrm{F}=2.87 ; \mathrm{p}=0.002)$ are obtained with food A1: $27.5 \pm 1.9 \mathrm{~g}$ and $0.25 \pm 0.15 \%$ /d respectively. It took 812.6 Congolese francs to develop food A1, 942.6 congolese francs to produce the A2 ration and 836.6 congolese francs to produce food A3. The A1 ration is the one that gave a better compromise in price and quality by promoting fish growth at a lower cost $(3.827$ congolese francs).
\end{abstract}

Keywords: Clarias gariepinus, food, growth performance, food efficiency, economic approach.

\section{Introduction}

Fish remains one of the foodstuffs perfectly integrated into the diet in the Democratic Republic of Congo. It lends itself to a variety of culinary combinations, from the preparation of fresh or smoked fish in sauce to salted fish (Diayeno, 2016). It is one of the alternatives to solve the problem of malnutrition in the country because it contains proteins of high biological value and contains essential amino acids (Fiogbe et al., 2009) and essential fatty acids of the omega 3 and 6 category whose metabolic role is obvious (Mbadu et al., 2017).

Today, more than $43 \%$ of the fish found on the world market come from fish farming, compared to only $9 \%$ in 1980. Aquaculture continues to grow at a faster rate than all other sectors of food production of animal origin. This prodigious growth is the result of research and innovations in the control of farm management and especially in feed (Ouédraogo, 2014).

Debates about the availability and use of feed for fish farming often focus on fish meal and fish oil. However, based on past trends and projections for the future, the sustainability and profitability of fish farming may benefit from a sustained supply of supplementary feeds, produced on an industrial scale as compound feeds in the form of pelleted feeds with an optimum protein content (FAO, 2012). 
Thus, it seems essential to valorise local agricultural by-products in order to offer Congolese fish farmers solutions adapted to the context of their farms. The aim of this study is to evaluate the production cost of Clarias gariepinus Burchell, 1822 fish (Siluriformes, Clariidae) by developing three types of feed based on local agricultural byproducts in the Democratic Republic of Congo. Specifically, it is a question of developing three types of feeds with different protein contents; evaluating the zootechnical parameters of the fish fed with the formulated feeds; evaluating the production cost of one $\mathrm{kg}$ of each type of feed; determining the production cost of one $\mathrm{kg}$ of fish with the three types of feeds and making simulations of financial profitability of the fish farming activity based on some local products and imported feeds.

The value of this study is obvious because the profitability simulations for feed and fish production discussed in this study will guide fish farmers and fish entrepreneurs in this area to increase their revenue while minimizing expenses.

\section{Material and Methods}

\subsection{Experimental Structure}

In the course of this study, six plastic bins $(50 \mathrm{~cm}$ long, $38 \mathrm{~cm}$ wide and $30 \mathrm{~cm}$ deep with a capacity of 50 litres each and interconnected by P.V.C. pipes) were put into operation. These tanks are composed of a continuous water renewal system in a closed circuit. They are intended for fish farming tests at the Limnology, Hydrobiology and Aquaculture Laboratory (located at $4^{\circ} 25^{\prime} 07.374^{\prime \prime}$ South, $15^{\circ} 18^{\prime} 31.588^{\prime \prime}$ East and at an altitude of $464 \mathrm{~m}$ ) of the Biology Department of the Faculty of Sciences of the University of Kinshasa in the Democratic Republic of Congo.

\subsection{Origin of Fish}

Biological material consists of the fry of Clarias gariepinus Burchell, 1822. The fish were purchased from the hatchery Mont-Thabor located in the commune of Mont-Ngafula, Kindele district on the road from Kimwenza to Kinshasa. The fry were obtained by artificial reproduction according to the methodology described by Hogendoor (1980); Pham (1980); Viveen et al, (1985); De Graaf and Janssen (1996); Ducarme and Micha (2003).

The fish had an average weight and initial mean size of $2.20 \pm 0.43 \mathrm{~g}$ and $62.16 \pm 2.00 \mathrm{~mm}$ respectively. A total of 180 fry were tested. In the laboratory, the fry were acclimatised for 6 days in an above-ground circular tank with a capacity of 1.000 litres before being loaded into the test tanks. The choice of this fish species is justified in the sense that it is one of the fish species whose farming is perfectly controlled (Adouvi, 2013), this fish is one of the most sold in the markets of Kinshasa (Masua et al., 2020) and is prized by the majority of the congolese (Lusasi et al., 2019b).

\subsection{Evaluation of the Physico-Chemical Parameters of the Water Used}

The dissolved oxygen $(\mathrm{mg} / \mathrm{L})$, temperature $\left({ }^{\circ} \mathrm{C}\right), \mathrm{pH}$ and conductivity $\left.(\mu \mathrm{S} / \mathrm{cm})\right)$ of the water in the tanks used in this experiment were measured using an oximeter (brand VOLTCRAFT DO-100) and a multi-parameter probe (brand HANNA Combo HI 99 1300). The evaluation of these parameters was carried out during the control fisheries that took place every 14 days (Munganga et al., 2020).

\subsection{Fish Feeding}

Three different types of food (table 1) at $25.2 \%, 41.01 \%$ and $51 \%$ crude protein were made from local agricultural by-products (soybean and palm kernel meal, wheat bran, maize, cassava and fish flours) as well as palm oil and cooking salt. These ingredients were selected according to their availability on the local market, their selling price but also the crude natural protein content (Lusasi et al., 2019a).

The fish were fed twice a day (9:00 am' and 3:00 pm') and the feed was distributed by hand. The daily amount of feed given to the fry corresponded to $10 \%$ of their total biomass as suggested by Lusasi et al., (2019a). After each control fishery, the amount of feed to be distributed in the days following these fisheries was adjusted according to the evolution of the average weight of fish. Feed A1 was distributed to the fish kept in tanks 1 and 2, fish reared in tanks 3 and 4 received feed A2 and feed A3 was intended for fish kept in tanks 5 and 6 . Fry of Clarias gariepinus were tested in duplicate and the experiment lasted 96 days.

Table 1. Centesimal composition of each type of food (N.P: natural protein)

\begin{tabular}{lccc}
\hline \multirow{2}{*}{ Ingredients } & \multicolumn{3}{c}{ Types of food } \\
\cline { 2 - 4 } & $\mathbf{A 1}(\mathbf{\%})$ & $\mathbf{A 2}(\mathbf{\%})$ & $\mathbf{A 3}(\mathbf{\%})$ \\
\hline Corn flour & 0.45 & 0.2 & 0.9 \\
Cassava flour & 0.1 & 0.02 & 0.3
\end{tabular}




\begin{tabular}{lccc} 
Fish flour & 13 & 39.0 & 8.4 \\
Soybean meal & 24 & 7.2 & - \\
Wheat bran & 1.5 & 1.8 & 3.4 \\
Palm kernel meal & 1.9 & 2.85 & 12 \\
\hline Total (\%) of N.P in the ration & $\mathbf{4 1}$ & $\mathbf{5 1 . 0}$ & $\mathbf{2 5}$ \\
\hline
\end{tabular}

\subsection{Weighing and Measuring Fish}

A growth-monitoring fishery was scheduled every 15 days, during which the weight (g) of fish was taken using a Salter electronic scale (accuracy 0.1g) and the size was measured to the nearest $0.1 \mathrm{~g}$ with a Digital Caliper electronic ichthyometer (Lusasi et al., 2019a).

\subsection{Zootechnical Parameters and Calculated Indices}

To estimate fish growth during the experiment and characterize the efficiency of use of the developed feed rations, the following zootechnical parameters and indices were calculated (Iga-Iga, 2008; Elegbe et al., 2015; Lusasi et al., 2019a):

- $\quad T S=(N f / N i) \times 100$

TS (\%): Survival rate, Nf: Final number of fish and Ni: Initial number of fish.

- $\quad P M: P M=B / N P$

PM: Mean Weight (g), B: Biomass (g) and NP: Number of Fish.

- $\quad G P M=P m f-P m i$

GPM: Average weight gain, Pmf: Average final weight of fish (g) and Pmi: Average initial weight of fish (g).

- $\quad C I J=(P f-P i) / D E$

CIJ: Individual Daily Growth (g/d), Pf: Final Weight (g), Pi: Initial Weight (g) and DE: Breeding Duration (d).

- $\quad C I=Q A S I / \mathrm{GPM}$

CI: Consumption Index, QASI: Quantity of Dry Food Ingested and GMC: Body Mass Gain (g).

\subsection{Evaluation of the Production Cost of Fish Feed Rations}

The purchase price of a given ingredient in a kilogram of feed is obtained by multiplying the price of one kilogram of that ingredient by its incorporation rate divided by 100 . The total production price of one kilogram of a feed ration is the sum of the purchase prices of each ingredient that makes up the ration (Ouédraogo, 2014; Elegbe et al., 2015; Lusasi et al., 2019a).

\subsection{Estimated Cost of Feed to Produce One Kilogram of Fish}

The feed cost of producing one kilogram of fish is estimated by multiplying the price of one kilogram of feed by the consumption index (Diayeno, 2016; Lusasi et al., 2019a).

\subsection{Data analysis and Statistical Processing}

The values obtained on the physico-chemical parameters of the waters used, the weight and linear growth, the survival rate and the weight gain of the fish were encoded on the Excel 2013 spreadsheet and then processed with Origin 6.1 and SPSS 20.1 software. Data related to zootechnical fish parameters were compared by analysis of variance with a one factor (ANOVA 1) to estimate the performance of the developed feed rations at the 5\% significance level.

\section{Results}

\subsection{Physico-Chemical Parameters of Water}

The variation in the different physico-chemical parameters (dissolved oxygen $(\mathrm{mg} / \mathrm{L})$, temperature $\left({ }^{\circ} \mathrm{C}\right), \mathrm{pH}$ and conductivity $(\mu \mathrm{S} / \mathrm{cm}))$ of the waters used for the fish farming experimented in this study is shown in table 2 below. 
Table 2. Physico-chemical parameters of the waters contained in the experimental tanks (Max: maximum; Min: minimum; Moy: average)

\begin{tabular}{cccccccccccccc}
\hline Bins & \multicolumn{3}{c}{$\begin{array}{c}\text { Dissolved oxygen } \\
(\mathbf{m g} / \mathbf{L})\end{array}$} & \multicolumn{3}{c}{ Temperature $\left({ }^{\circ} \mathbf{C}\right)$} & \multicolumn{3}{c}{$\mathbf{p H}$} & \multicolumn{4}{c}{ Conductivity $(\boldsymbol{\mu} \mathbf{S} / \mathbf{c m})$} \\
\cline { 2 - 17 } & Max & Min & Moy & Max & Min & Moy & Max & Min & Moy & Max & Min & Moy \\
\hline A1 & 6.1 & 3.8 & $5.18 \pm 0.73$ & 28.5 & 26.3 & $27.8 \pm 0.59$ & 6.15 & 4.97 & $5.84 \pm 0.39$ & 197 & 93 & $148.16 \pm 42.16$ \\
A2 & 6.7 & 5.2 & $5.95 \pm 0.4$ & 27.8 & 25.9 & $27.8 \pm 0.62$ & 6.85 & 5.13 & $6.29 \pm 0.36$ & 201 & 98 & $150.83 \pm 42.16$ \\
A3 & 6.2 & 5.3 & $5.78 \pm 0.37$ & 27.8 & 25.6 & $27.8 \pm 0.62$ & 6.16 & 5.12 & $6.03 \pm 0.23$ & 203 & 93 & $151.83 \pm 45.5$ \\
\hline
\end{tabular}

The results in table 2 show that, on average, dissolved oxygen during the experiment ranged from $5.18 \pm 0.73$ to $5.95 \pm 0.4 \mathrm{mg} / \mathrm{L}$ and, on average, remained within the range conducive to the growth of the experimental poisons. The average temperature of all treatments met the requirement (or $27.8 \pm 0.62^{\circ} \mathrm{C}$ ) of the desired values for good growth of Clarias gariepinus poisons in livestock. The $\mathrm{pH}$ showed slightly acidic values (tank A1: $5.84 \pm 0.39$; $\operatorname{tank}$ A2: $6.29 \pm 0.36$ and tank A3: $6.03 \pm 0.23$ ), but could not disturb the growth of fish. The conductivity of the water varies between $148.16 \pm 42.16$ and $151.83 \pm 45.5 \mu \mathrm{S} / \mathrm{cm}$.

\subsection{Zootechnical Parameters of Fish}

Table 3 summarizes the growth performance of Clarias gariepinus fry fed with the experimental feeds for 96 days.

Table 3. Growth performance of fry of Clarias gariepinus after 96 days (TS: Survival rate (\%); Pmi: Initial average weight (g); Pmf: Final average weight (g); Tmi: Initial average size (mm); Tmf: Final average size (mm); TCS: Specific growth rate (\%/d); Gpm: Average weight gain (g/d) and CI: Consumption index)

\begin{tabular}{ccccccccc}
\hline Types of food & Ts & Pmi & Pmf & Tmi & Tmf & Gpm & TCS & CI \\
\hline A1 & $13.33 \pm 4.03$ & $3.00 \pm 1.20$ & $27.5 \pm 1.9$ & $63.1 \pm 2.02$ & $138.65 \pm 6.67$ & $24.52 \pm 2.58$ & $0.25 \pm 0.15$ & $4.71 \pm 0.36$ \\
A2 & $70.00 \pm 3.87$ & $2.20 \pm 0.43$ & $11.6 \pm 0.95$ & $62.16 \pm 2.00$ & $94.10 \pm 4.18$ & $9.40 \pm 0.86$ & $0.09 \pm 0.21$ & $11.39 \pm 2.46$ \\
A3 & $73.3 \pm 2.5$ & $2.80 \pm 0.77$ & $9.2 \pm 0.41$ & $65.90 \pm 2.26$ & $75.00 \pm 3.14$ & $6.41 \pm 0.64$ & $0.06 \pm 0.2$ & $18.12 \pm 3.83$ \\
\hline
\end{tabular}

\subsubsection{Survival Rate}

The survival rate is $73.3 \pm 2.5 \%$ in fish fed the A3 diet, $70.00 \pm 3.87 \%$ in fry fed the A2 diet and $13.33 \pm 4.03 \%$ in fish fed the 1 diet. Analysis of variance (significance level 5\%) indicates that fish survival rates vary significantly $(\mathrm{F}=5.61 ; \mathrm{p}=0.01)$ depending on feed type (figure 1$)$. 


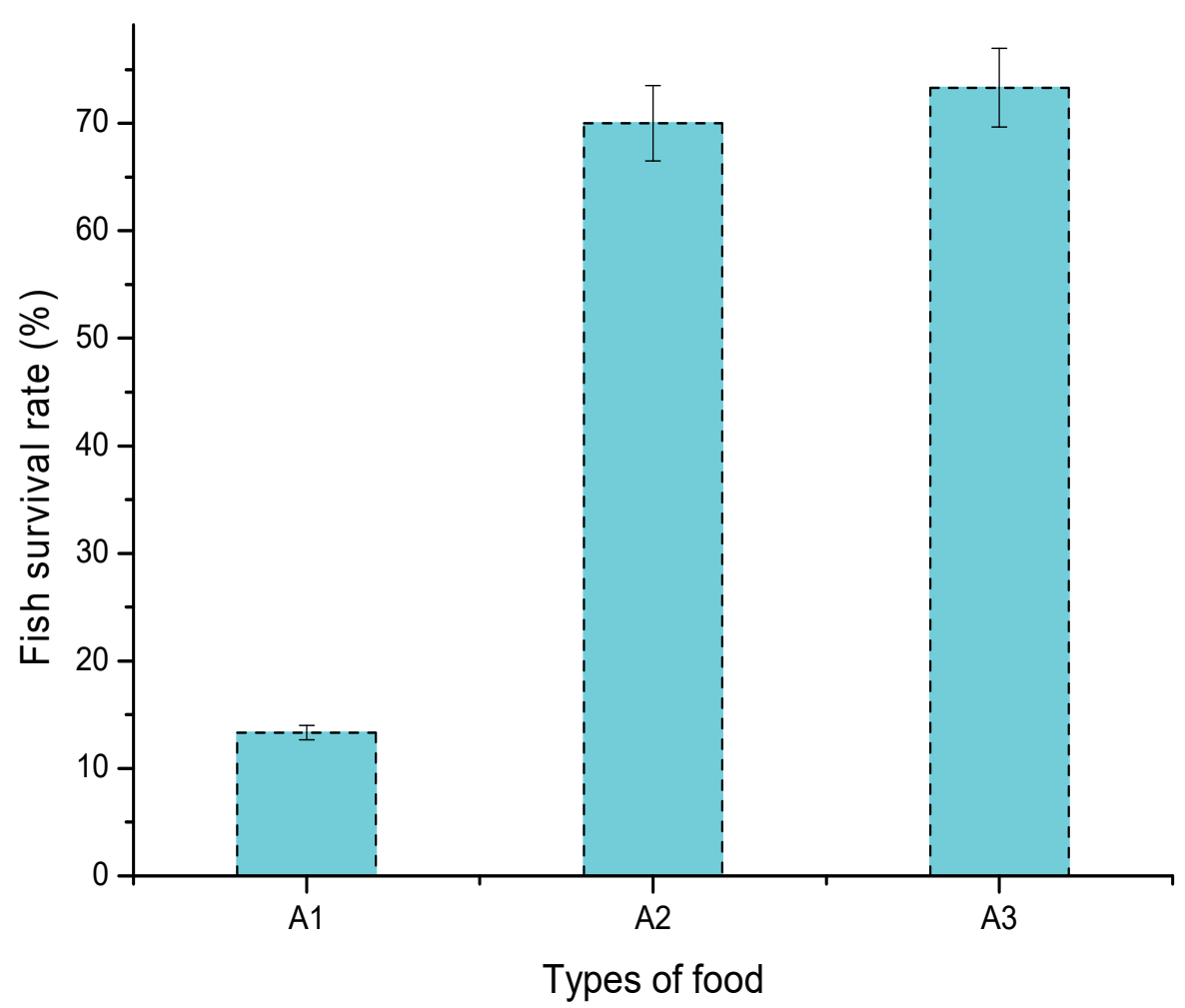

Figure 1. Variation in fish survival rates by feed type

\subsubsection{Average Final Weight}

The weight growth curves maintained an upward trend during the test. The highest value (or $27.5 \pm 1.9 \mathrm{~g}$ ) was recorded in fish receiving feed A1, followed by fish receiving feed A2 (or 11.6 $\pm 0.95 \mathrm{~g}$ ) and the lowest value was recorded in fish receiving feed A3 (or $9.2 \pm 0.41 \mathrm{~g}$ ). Analysis of variance shows a significant difference between the rations at the $5 \%$ significance level $(\mathrm{F}=48.48 ; \mathrm{p}=0.001)$. The paired multiple comparison test $(\mathrm{LSD}=0.67)$ indicates that feed $\mathrm{A} 1$ has a more significant influence on fry weight than feed $\mathrm{A} 2$, which in turn has a significant impact on the same parameter as feed A3 (figure 2). 


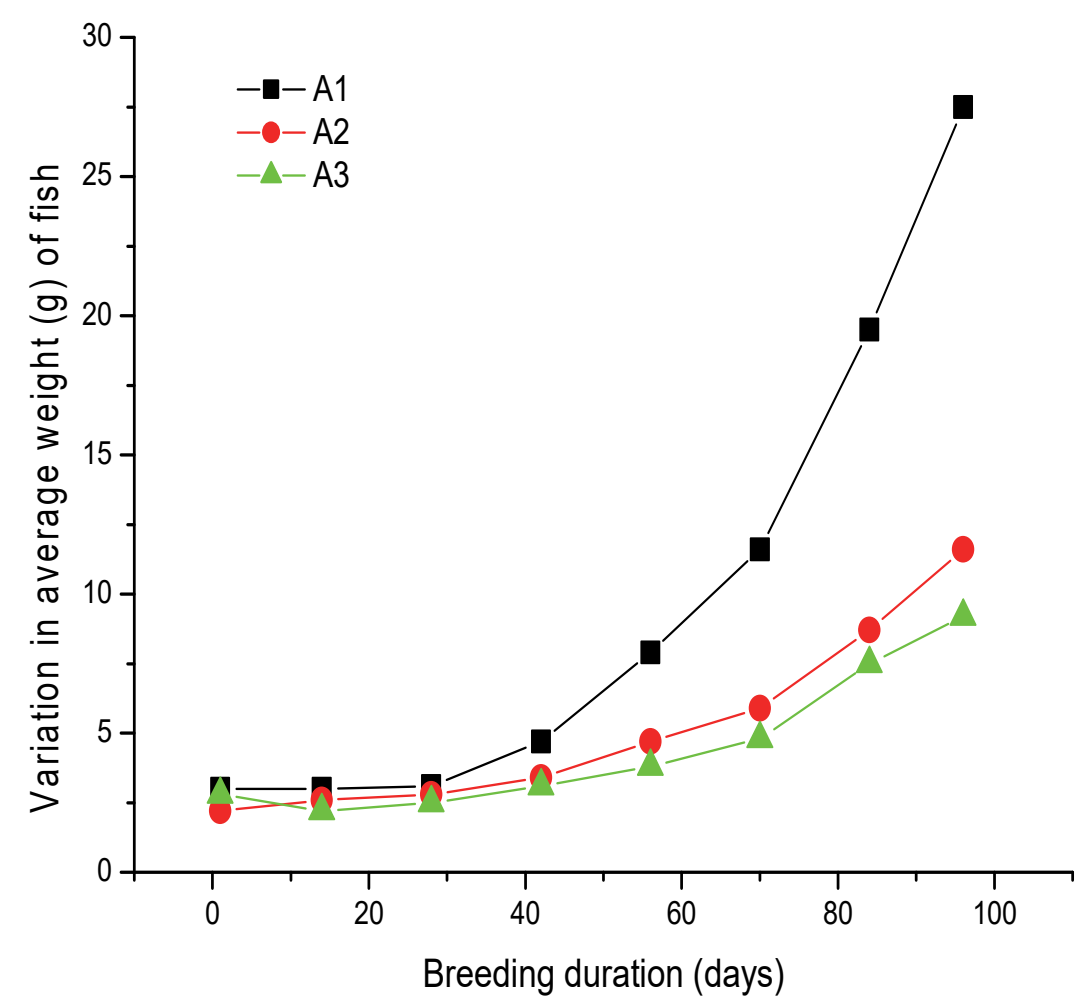

Figure 2. Evolution of the average weight ( $\mathrm{g}$ ) of fish according to the types of food

\subsubsection{Final Average Size}

The final average size of fish varies according to the type of food. Analysis of variance indicates a significant difference between rations $(F=600.98 ; p=0.039)$, the LSD test $(0.66)$ shows that the A1 ration had a more significant effect on linear fish growth (ranging from $63.1 \pm 2.02$ to $138.6 \pm 6.67 \mathrm{~mm}$ ) than the A2 ration (ranging from $62.16 \pm 2.00$ to $94.10 \pm 4.18 \mathrm{~mm}$ ), which significantly influenced fry size than the A3 ration (ranging from $65.90 \pm 2.26$ to $75.00 \pm 3.14 \mathrm{~mm}$ ) (figure 3). 


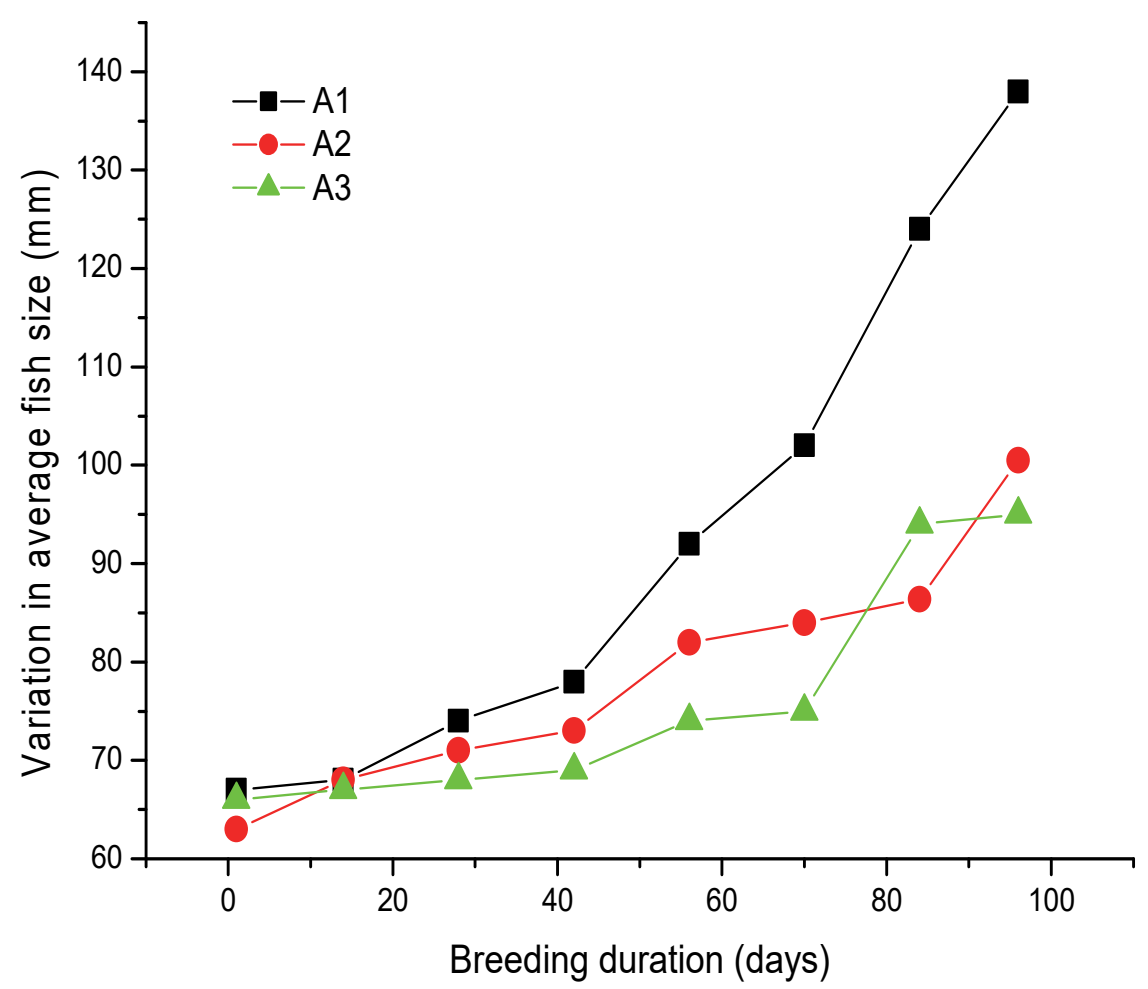

Figure 3. Variation in average size ( $\mathrm{mm}$ ) of fish according to feed types

\subsubsection{Average Weight Gain}

The weight gain of farmed fish has evolved with the types of feed distributed. Analysis of variance $(\mathrm{F}=2.87 ; \mathrm{p}=$ 0.002 ) shows that feed A1 significantly influenced fish weight gain (or $24.52 \pm 2.58 \mathrm{~g} / \mathrm{d}$ ) followed by feed A2 (or $9.40 \pm 0.86 \mathrm{~g} / \mathrm{d}$ ) and feed A3 resulted in low weight gain (or $6.41 \pm 0.64 \mathrm{~g} / \mathrm{d}$ ) 5 (figure 4).

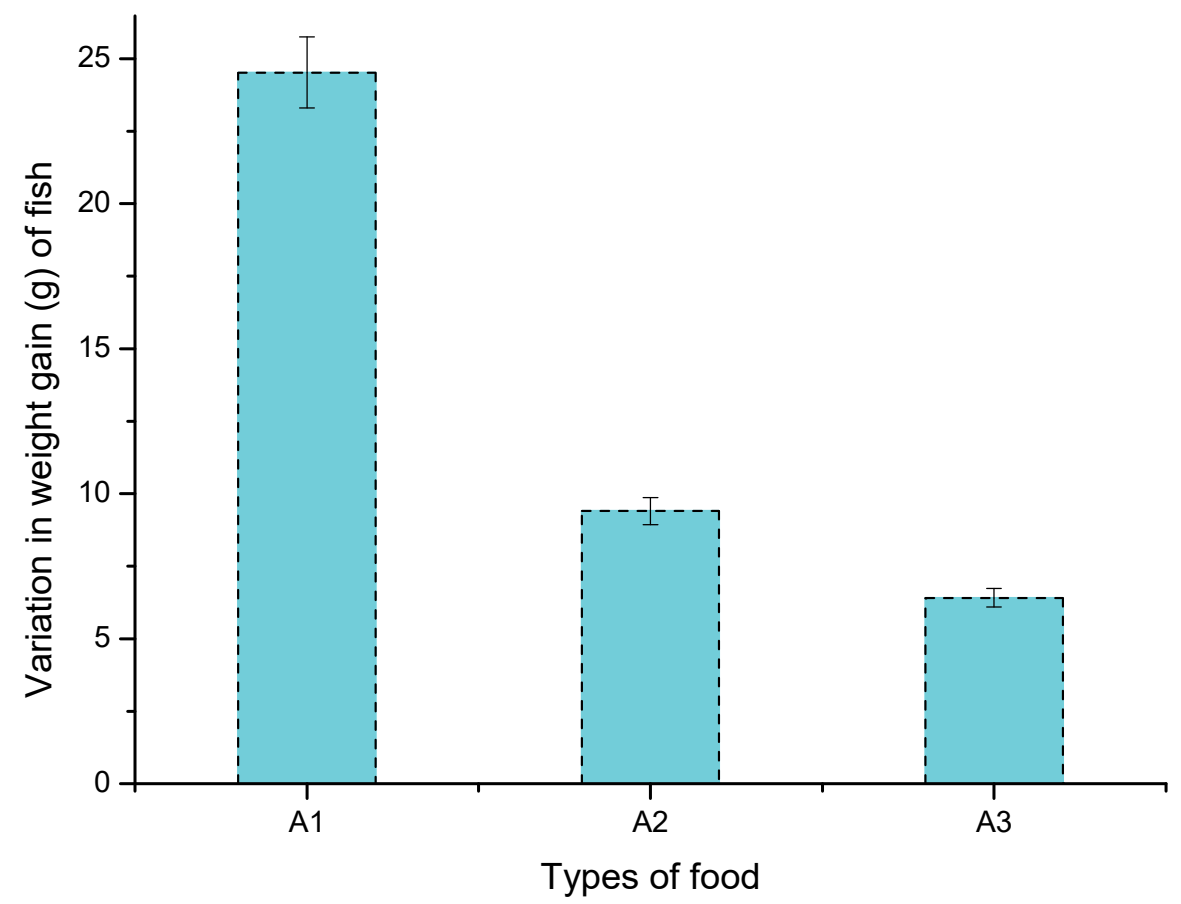

Figure 4. Variation in weight gain (g) of fish in relation to feed types 


\subsubsection{Specific Growth Rate}

With regard to the specific growth rate, the feed rations developed differed significantly $(\mathrm{F}=3.21 ; \mathrm{p}=0.001)$; feed A1 had a favourable effect on this parameter (or $0.25 \pm 0.15 \% / \mathrm{d}$ ) compared to feed A2 (or $0.09 \pm 0.21 \% / \mathrm{d}$ ), which in turn had a significantly greater influence on fish growth than feed A3 (or $0.06 \pm 0.2 \% / d$ ) (figure 5).

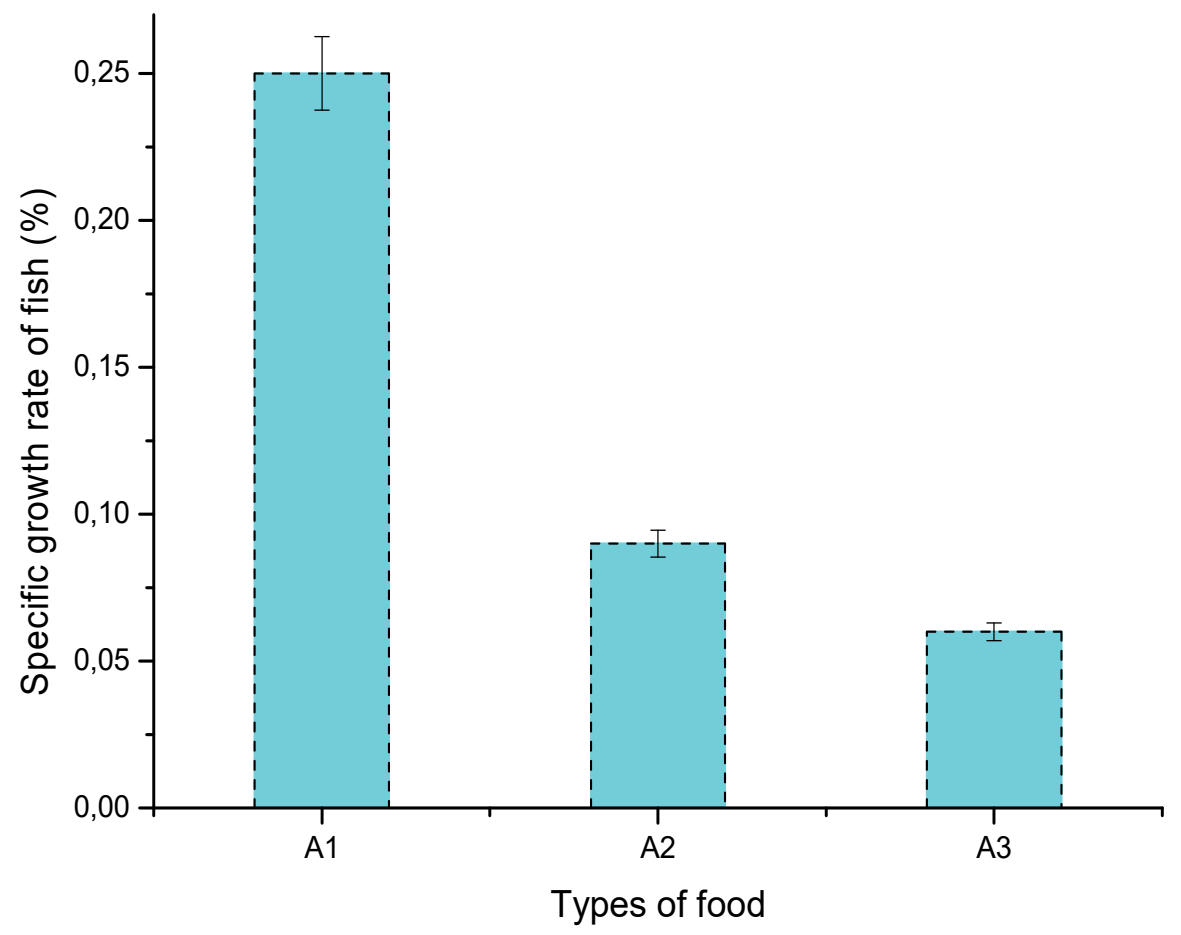

Figure 5. Variation in specific growth rate of fish by feed type

\subsubsection{Consumption Index}

The index of food consumption by fish varies very significantly by food type $(\mathrm{F}=71.861 ; \mathrm{p}=0.001)$. With the critical value of $0.05 \%$, the fish fed with food A3 are those that recorded a high value (or 18.12 \pm 3.83 ) of this parameter followed by those fed with food A2 (or 11.39 \pm 2.46 ). Fish fed food A1 recorded the lowest value (or $4.71 \pm 0.36$ ) of feed conversion efficiency (figure 6). 


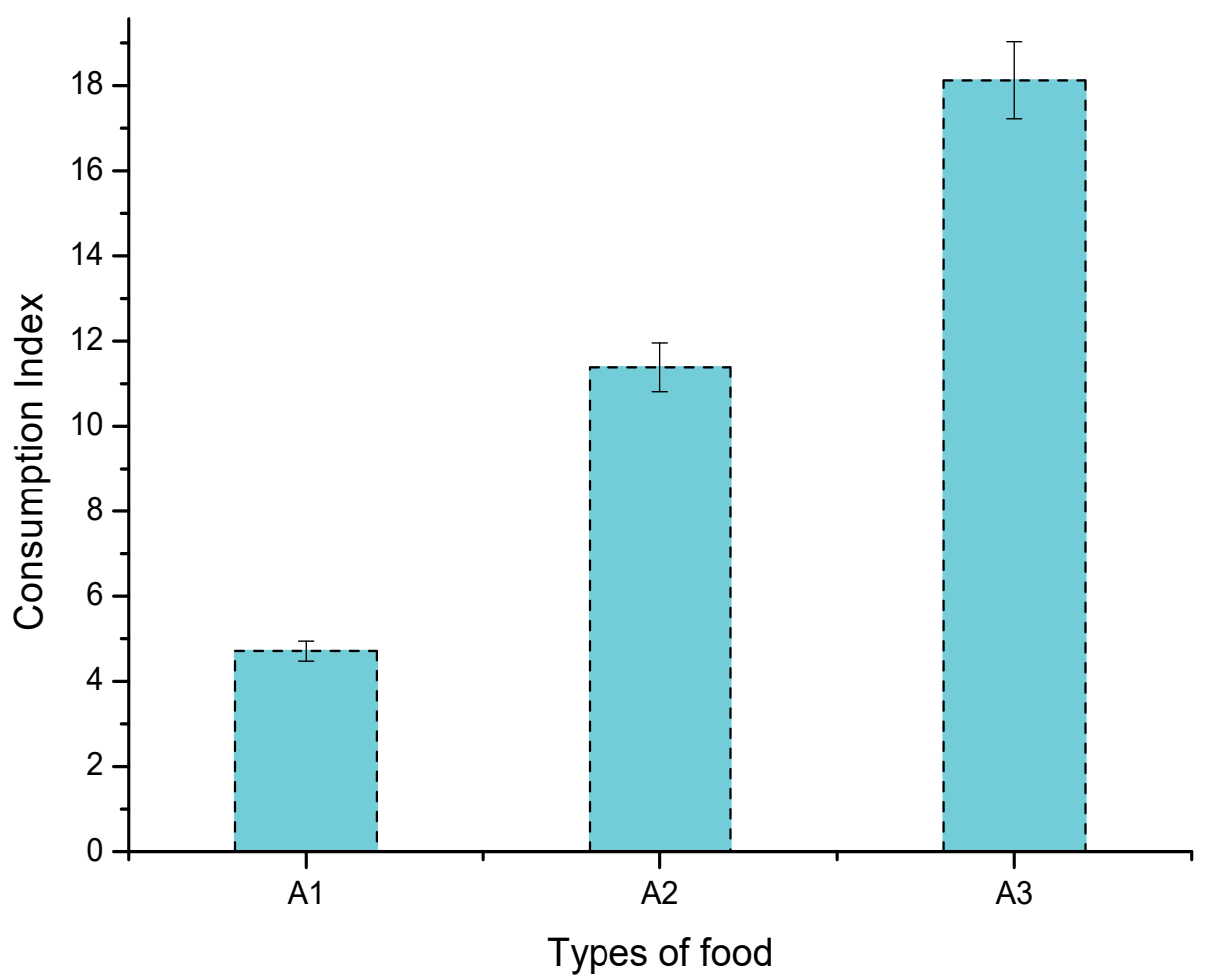

Figure 6. Varation of the consumption index according to type of food

\subsection{Economic Aspects of Fish Feed}

\subsubsection{Price Per Kilogram of Food Developed}

The price in Congolese Francs (CF) of production of one kilogram of each type of food is given in table 4.

Table 4. Cost (FC) of producing one kilogram of the different types of food developed ( $1 \mathrm{USD}=1.750 \mathrm{CF}$ )

\begin{tabular}{lcccc}
\hline \multicolumn{1}{c}{ Ingredients } & Price (FC) & \multicolumn{3}{c}{ Types of food } \\
\cline { 3 - 5 } & & $\mathbf{A 1}$ & $\mathbf{A 2}$ & $\mathbf{A 3}$ \\
\hline Corn flour & 800 & $800 \times 5 / 100=40$ & $800 \times 2 / 100=16$ & $800 \times 10 / 100=80$ \\
Cassava flour & 800 & $800 \times 5 / 100=40$ & $800 \times 1 / 100=80$ & $800 \times 10 / 100=80$ \\
Wheat bran & 200 & $200 \times 10 / 100=20$ & $200 \times 12 / 100=24$ & $200 \times 17 / 100=34$ \\
Palm kernel meal & 1.000 & $1.000 \times 10 / 100=100$ & $1.000 \times 15 / 100=150$ & $1.000 \times 50 / 100=500$ \\
Fish flour & 1.000 & $1.000 \times 20 / 100=200$ & $1.000 \times 50 / 100=500$ & $1.000 \times 13 / 100=130$ \\
Soybean meal & 800 & $800 \times 50 / 100=400$ & $800 \times 20 / 100=160$ & - \\
Palm oil & 600 & $600 \times 1.6 / 100=9.6$ & $600 \times 1.6 / 100=9.6$ & $600 \times 1.6 / 100=9.6$ \\
Kitchen salt & 500 & $500 \times 0.6 / 100=3$ & $500 \times 0.6 / 100=3$ & $500 \times 0.6 / 100=3$ \\
\hline \multicolumn{1}{c}{ Total price in CF } & $\mathbf{8 1 2 . 6}$ & $\mathbf{9 4 2 . 6}$ & $\mathbf{8 3 6 . 6}$ \\
\hline
\end{tabular}

From the data in Table 4 above, it takes $942.6 \mathrm{CF}$ to make one kilogram of food A2, 836.6 CF to develop one kilogram of food A3 and 812.6 CF to produce one kilogram of food A1. 


\subsubsection{Cost of Producing One Kilogram of Fish With Different Feed Types}

The price in CF of producing one kilogram of fish with the different types of feed rations formulated is given in table 5 below.

Table 5. Production cost in $\mathrm{CF}$ of one kilogram of fish with the feed produced $(\mathrm{CF}=$ Congolese Franc; $\mathrm{CI}=$ Consumption Index)

\begin{tabular}{cccc}
\hline Types of food & Price (CF) & CI & Cost (FC) of fish production \\
\hline A1 & 812.6 & 4.71 & 3.827 \\
A2 & 942.6 & 11.39 & 10.736 \\
A3 & 836.6 & 18.12 & 15.159 \\
\hline
\end{tabular}

According to the information in Table 5, it is necessary to spend $15.159 \mathrm{CF}$ to produce one kilogram of fish with feed $\mathrm{A} 3$ while it is necessary to spend $10.736 \mathrm{CF}$ to produce one kilogram of fish with feed A2 and $3.827 \mathrm{CF}$ to have one kilogram of fish with feed A1.

\section{Discussion}

The physico-chemical parameters of the waters remained within the range of optimal values recommended for the rearing of Clarias gariepinus fish. Average dissolved oxygen concentrations varied between 5.18 and $5.95 \mathrm{mg} / \mathrm{L}$ in the ponds. These levels are higher than the $3 \mathrm{mg} / \mathrm{L}$ indicated by Viveen et al., (1985); Baras and Jobling (2002), which are favourable for the growth of fingerlings of $C$. gariepinus. The hydrogen potential varied between 4.97 and 6.85 during the experiment. The $\mathrm{pH}$ values found in this study are thought to be due to the alkalinity of the water coming from the taps. In fact, these values are at the lower limit of the optimal limit (6.5 to 8 ) favourable to good growth of Clarias (Kanangire, 2001; Adouvi, 2013). The temperature was relatively high in all the basins and varied globally between 25.6 and $28.5^{\circ} \mathrm{C}$ throughout the experiment and is comparable to that reported by Franco et al., (2017) (or between 24 and $35^{\circ} \mathrm{C}$ ), who stipulate that the optimum temperature for the growth of $C$. gariepinus is between 26 and $30^{\circ} \mathrm{C}$.

With regard to the zootechnical parameters of the fish reared, the survival rate of the fish varied significantly depending on the type of feed. It was high in treatments $\mathrm{A} 3$ (or $73.3 \pm 2.5 \%$ ) and $\mathrm{A} 2$ (or $70.00 \pm 3.87 \%$ ) and lower in treatment A1 (or $13.33 \pm 4.03 \%$ ). These rates remain low compared to those obtained by Elegbe et al., (2015) (or 80 and $87.78 \%$ ) at the end of the trial in Clarias gariepinus fry. The recorded mortalities could be explained by the stress related to fish handling during control fisheries but also to the period prior to the acclimatization of the fry (Ouédraogo, 2014); Soumaïla et al., (2016). The final average weight of fish also varied according to the types of food. The highest value (or $27.5 \pm 1.9 \mathrm{~g}$ ) was recorded in fish fed with food A1. For this parameter, these results are higher than those obtained by de Ducarme and Micha (2003) (or 1.4 to $4.6 \mathrm{~g}$ ) on the intensive production technique of African catfish, C. gariepinus. Diayeno (2016) developed a feed for the larviculture of C. gariepinus and noted a lower weight growth (or R1: $0.03 \pm 0.00$ to $10.99 \pm 0.33 \mathrm{~g}$, R2: $0.03 \pm 0.00$ to $9.38 \pm 0.32 \mathrm{~g}$ and R3: $0.03 \pm 0.00$ to $7.91 \pm 0.01 \mathrm{~g}$ ). The performance of food A1 would be due to the combination of the ingredients used to develop this food because variations in the digestibility of a food also depend on the nutritional quality of the ingredients and their rate of incorporation (Elegbe et al., 2015; Lusasi et al., 2019a). The best specific growth rate of fish was obtained in fish fed with feed A1 (or $0.25 \pm 0.15 \% / \mathrm{d}$ ) prepared with soybean meal and the lowest are those obtained with feeds A2 (or $0.09 \pm 0.21 \% / \mathrm{d}$ ) and A3 (or $0.06 \pm 0.2 \% / \mathrm{d}$ ) in which soybean was partially replaced respectively by fish meal and palm kernel meal which influenced the efficiency of these feeds (Otchoumou et al., 2011). The observations made are close to those noted by Gandaho (2007) (or $0.19 \% / \mathrm{d}$ ) who developed feed rations with the leaves of Moringa oleifera to improve the growth of C. gariepinus. On the other hand, these values remain below $1.67 \pm 0.23 \% / \mathrm{d}$ and $1.88 \pm 0.03 \% / \mathrm{d}$ obtained by Elegbe et al., (2015) on the co-crop of Clarias gariepinus-Oreochromis niloticus in Benin.

The production price of one kilogram of a feed ration varies from one food to another. The results obtained showed that feed A2 is the most expensive (or 942.6 CF) followed by feed A3 (or 836.6 CF) and feed A1 is the least expensive (or 812.6 CF). However, Lusasi et al., (2019a) reveal that in Kinshasa markets in the Democratic Republic of Congo, imported food costs $67.500 \mathrm{CF}$ per kilogram and another food that can be ordered from France or Belgium would cost up to $185.000 \mathrm{CF}$ per kilogram. Iga-Iga (2008) has also made the same observation and confirms that it is preferable to rely on local agricultural by-products rich in animal and vegetable protein to formulate feed for farmed fish in order to minimize production costs. Indeed, it has been shown that it is less 
expensive to produce one kilogram of fish with feed A1 (or 3.827 CF) than with feed A2 (or 10.736 CF) and feed A3 (or 15.159 CF). These results do not agree with those obtained by Iga-Iga (2008) who developed two feed rations for Oreochromis niloticus based on local inputs in Gabon. According to the results reported by the latter author, it is necessary to spend 257 FCFA (equivalent to 675 FCFA) to produce one kilogram of fish with ration 1 , and producing one kilogram of fish with ration 2 will cost 300.3 FCFA (equivalent to 810 FCFA). Elegbe et al., (2015) also pointed out that the production cost of Clarias gariepinus and Oreochromis niloticus raised in coculture is lower with the local feed produced in Benin (830.4 FCFA equivalent to 2.035 FCFA) than with the imported feed (911.4 FCFA equivalent to 2.530 FCFA). Lusasi et al., (2019a) made the same observations by developing four feed rations based on local animal and plant by-products for the breeding of Distichodus maculatus in the Democratic Republic of Congo.

\section{Conclusion}

Faced with the constraints linked to the lack of compound feeds in the form of granules faced by congolese fish farmers, we developed three types of feeds based on local agricultural by-products to test the cost of producing Clarias gariepinus Burchell, 1822 fish using these feeds. The results obtained indicated that the highest final average weight $(\mathrm{g})$ of fish and specific growth rate $(\% / \mathrm{d})$ were obtained with feed A1 (or $27.5 \pm 1.9 \mathrm{~g}$ and $0.25 \pm 0.15 \% / \mathrm{d}$ respectively) containing $41 \%$ crude protein. Analysis of the economic approach to the feed rations developed revealed that there is a considerable difference in the production price of one kilogram of feed and fish with the three types of formulated feeds. With reference to the growth performance of the fish studied, feed A1 therefore presented the best compromise between price and quality by covering the nutritional requirements of the farmed fish in the best and cheapest way. These results confirm the economic and technical interest in using local agricultural by-products for the profitability of congolese fish farming.

\section{Acknowledgements}

We thank the persons in charge of the Laboratory of Limnology, Hydrobiology and Aquaculture of the Department of Biology of the Faculty of Sciences of the University of Kinshasa for the material placed at our disposal as well as Mr Léon BWAMAYAMA for having facilitated the acquisition of the fry of Clarias gariepinus, biological support of this study.

\section{References}

Adouvi, E.C. (2013). Effets de la substitution de la farine de poisson par la farine des graines de Néré (Parkia biglobosa) \& de la farine du tourteau de soja (Glycine maxima) sur la croissance \& la survie des juvéniles de Clarias gariepinus (Burchell, 1822). Mémoire de fin de formation pour l'obtention du Diplôme de Licence Professionnelle en Sciences Agronomiques. Université d'Abomey Calavi, Benin, 43 p.

Baras, E., \& Jobling, M. (2002). Dynamics of intracohort cannibalism in cultured fish. Aquaculture Research, 33, 461-479. https://doi.org/10.1046/j.1365-2109.2002.00732.x

De Graaf, J. H., \& Janssen, J. N. L. (1996). Artificial reproduction and pond reaming of the African Catfish. Clarias gariepinus: in Sub-Sahara Africa-A Hand book FAO, Fisheries. Technical paper n³6, Rome, FAO, $37 \mathrm{p}$.

Diayeno, K. M. (2016). Mise au point d'un aliment à base des produits \& sous-produits agricoles locaux pour larviculture de Clarias gariepinus Burchell, 1822. Mémoire de licence en sciences Biologiques. Université de Kinshasa, Kinshasa, 56 p.

Ducarme, C., \& Micha, J. C. (2003). Technique de production intensive du poisson Chat-Africain. Clarias gariepinus. Tropicultura, 21(4), 189-198.

Elegbe, A. H., Toko, T. H., Agbohessi, P., Ble, C., Banag, A., Chikou, A., Tomedi, E. M., \& Laleye, P. (2015). Coculture Clarias gariepinus-Oreochromis niloticus: quels avantages pour l'amélioration des performances zootechniques \& économiques des poissons élevés dans les « whedos » du delta de l'Ouémé au Bénin ? Int. J. Biol. Chem. Sci., 9(4), 1937-1949. https://doi.org/10.4314/ijbcs.v9i4.19

FAO. (2012). La situation mondiale des pêches \& de l'aquaculture. Rome, Italy. Disponible sur. Retrieved from http://www.fao.org/docrep/016/i2727f/i2727f00.htm

Fermon, Y. (2008). La pisciculture de subsistance en étangs en Afrique: Manuel technique. Acf-International, Net Work, $294 \mathrm{p}$.

Fiogbe, E. D., Akitikpa, B., \& Accodji, J. M. M. (2009). Essais de mise au point de formules alimentaires à base d'azolla (Azolla microphylla Kaulf) \& de sous-produits locaux pour la pisciculture rurale du Tilapia Oreochromis niloticus L. Int. J. Biol. Chem. Sci., 3(2), 398-405. https://doi.org/10.4314/ijbcs.v3i2.44511 
Franco, M., Mabruki, N., Benge, I., Ekyamba, J. F., Ngamba, M., \& Busanga, A. K. (2017). Effets des aliments à base des ingrédients locaux sur la survie \& sur la croissance des larves de Clarias gariepinus dans la région de Kisangani, République Démocratique du Congo. International Journal of Innovation and Scientific Research, 30(2), 149-158.

Gandaho, P. S. (2007). Etude des performances de croissance des juvéniles de Clarias gariepinus (Burchell, 1822) nourris à base de Moringa oleifera \& de sous-produits locaux. Thèse de Doctorat.

Hogendoor, H. (1980). Controlled propagation of the African catfish, Clarias lazera, Feeding and growth of fry. Aquaculture, 21, 233-241. https://doi.org/10.1016/0044-8486(80)90133-7

Iga-iga, R. (2008). Contribution à la mise au point d'aliments pour tilapia Oreochromis niloticus à base d'intrants locaux: cas du Gabon. Mémoire de DEA en sciences Agronomiques. AGRO CAMPUS Ouest, $37 \mathrm{p}$.

Kanangire, C. K. (2001). Effet de l'alimentation des poissons avec Azolla sur l'écosystème agropiscicole au Rwanda. Dissertation présentée en vue de l'obtention du grade de Docteur en Sciences. Facultés Universitaires Notre Dame de la Paix, Namur, Belgique, 220 p.

Lusasi, S. W., Makiese, M. P., Kunonga, N. L., Munganga, K. C., Kavumbu, M. S., \& Pwema, K. V. (2019b). Proportion de vente des poissons frais locaux \& importés dans les marchés de Kinshasa en République Démocratique du Congo (cas des marchés de la Liberté de Masina \& Central de Kinshasa). Journal of Applied Biosciences, 141, 14353-14363. https://dx.doi.org/10.4314/jab.v141i1.2

Lusasi, S. W., Pwema, K. V., Munganga, K. C., Kavumbu, M. S., \& Mutambwe, S. (2019a). Mise au point d'un aliment pour Distichodus maculatus Boulenger, 1898 à base des sous-produits agricole disponibles localement. Afrique SCIENCE, 15(2), 238-248.

Masua, T. B., Lusasi, S. W., Munganga, K. C., Wumba, M. P., Kavumbu, M., \& Pwema, K. V. (2020). Inventory of fresh fish marketed in the markets of Kinshasa in the Democratic Republic of Congo (case of the Gambela and Matete markets). International Journal of Applied Research, 6(4), 102-108.

Mbadu, Z.V., Kakuma, L. E., Mutambwe, S., Usimesa, N., \& Yandju, M. C. (2017). Effets de trois types d'aliments sur la croissance des alevins de Parachanna insignis Sauvage, 1884 (Channidae, Perciformes) élevés en bacs. Congo Sciences, 5(2).

Munganga, K. C., Kavumbu, M. S., Bipendu, M. N., Kunonga, N. L., Lusasi, S. W., \& Pwema, K. V. (2020). Evaluation de la Qualité Écologique de la Rivière Musolo à Kinkole Basée sur les Macroinvertébrés Benthiques (Kinshasa, R.D Congo). European Journal of Scientific Research, 155(2), 162 -176.

Otchoumou, K. A., Blé, M. C., Alla, Y. L., \& Corraze, G. (2011). Utilisation des huiles végétales en pisciculture en remplacement des huiles de poisson: cas de l'huile de palme dans l'alimentation des juvéniles du poissonchat (Heterobranchus longifilis). INRA, UR 1067 «Nutrition, Métabolisme \& Aquaculture, Pôle d'Hydrobiologie, France. F. Tech. \& Doc. Vulg.: 43-47.

Ouédraogo, B. S. (2014). Analyse de l'offre des produits \& sous-produits agricoles utilisés pour la fabrication d'aliments destinés au poisson-chat africain Clarias gariepinus (Burchell, 1822). Mémoire de DEA en sociologie \& économie rurale, Université Polytechnique de Bobo-Dioulasso (UPB), Burkina Faso, 72 p.

Pham, A. (1980). Contribution à l'étude de la biologie de Clarias lazera (poisson claridae): Survie des alevins en étang. Notes \& documents sur pêche \& pisciculture. CTFT, nouvelle série, $n^{\circ} 20$, France, 11-19 p.

Soumaïla, M., Kedegnon, G., Agadjihouede, H., Montchowui, E., Dahouda, M., Mensah, G. A., \& Lalèyè, P. (2016). Effets de la substitution de la farine de poisson par la farine d'Achatina fulica (Férussac, 1821) sur la survie \& la croissance des alevins de Clarias gariepinus (Burchell, 1822) au Bénin. Bulletin de la Recherche Agronomique du Bénin (BRAB), ISSN sur papier (on hard copy): 1025-2355 \& ISSN en ligne: 1840-7099.

Viveen, W. J. A., Richter, C. J. J., Van Oordt, P. G., Janssen, J. N. L., \& Huismon, C. A. (1985). Manuel de pisciculture du poisson-chat africain (Clarias gariepinus). Département de pisciculture \& des pêches de l'Université Agronomique de Wageningen, Pays-Bas, 93.

\section{Copyrights}

Copyright for this article is retained by the author(s), with first publication rights granted to the journal.

This is an open-access article distributed under the terms and conditions of the Creative Commons Attribution license (http://creativecommons.org/licenses/by/4.0/). 